\title{
Tłumaczenie - z poprawkami Jana Maleckiego - Ewangelii według św. Mateusza przez Stanisława Murzynowskiego
}

\author{
Jakub Z. Lichański
}

Warszawa

zjlichan@uw.edu.pl (D) https://orcid.org/0000-0002-1943-5069

Pozornie może się wydawać, iż kwestie określone w tytule niniejszych rozważań są już dobrze opisane ${ }^{1}$. Jak wiemy, królewieckie wydanie z roku 1551 Ewangelii według św. Mateusza w przekładzie Stanisława Murzynowskiego wywołało ostrą replikę Jana Sandeckiego-Maleckiego. Kwestie te opisał poza językoznawcami m.in. Barycz (1962, s. 75-77)². Problemy dotyczyły przede wszystkim precyzji translacji:

„ukazała się pierwsza jaskółka przedsięwzięcia Seklucjanowego - przekład ewangelii św. Mateusza. Zmobilizowało to od razu czujność Maleckich, zaostrzoną równoczesnym wezwaniem ks. Albrechta dokonania oceny wydanego fragmentu. Doczekał się on rzeczywiście integralnej, niezwykle ostrej superkrytyki zarówno od strony językowej jak treściowej («Haereses et errores in Commentario Jo. Secluciani in Mathaeum»). Rozumiejąc dobrze, że samą krytyką i negacją nie osiągnie celu, odczekał Jan Sandecki z odesłaniem oceny do czasu ukazania się części pierwszej Nowego Testamentu tj. «czterech ewangelistów» w październiku tegoż 1551 roku. Uruchomiwszy naprędce prasy drukarskie, odbił próbny arkusz czterokartkowy własnego tłumaczenia ewangelii św.

1 Wskazać warto Brücknera (1906, s. 15, 17, 32) - tekst modlitwy Ojcze nasz z roku 1475 ze Statuta synodalia episcoporum Wratislaviensium, s. 33, 47, 49, 51, 58, 71, 74, 76, 78, 83, strona z ortografią Murzynowskiego z Nowego Testamentu (1551), gdzie reprodukowane są karty tytułowe oraz fragmenty wydań Biblii bądź jej fragmentów (sam wykład na temat historii języka jest już nieco przestarzały). Najpełniejsze omówienie przekazów rękopiśmiennych Modlitwy Pańskiej w języku polskim por. Masłej (2016); Abramowicz \& Ławski (2009) i Abramowicz \& Ławski (2010) - badacze zajmują się raczej recepcją idei niż opisem źródeł, w tym np. tłumaczeń.

2 Stan badań opisała Lenartowicz-Zagrodna (2011, s. 108-109). 


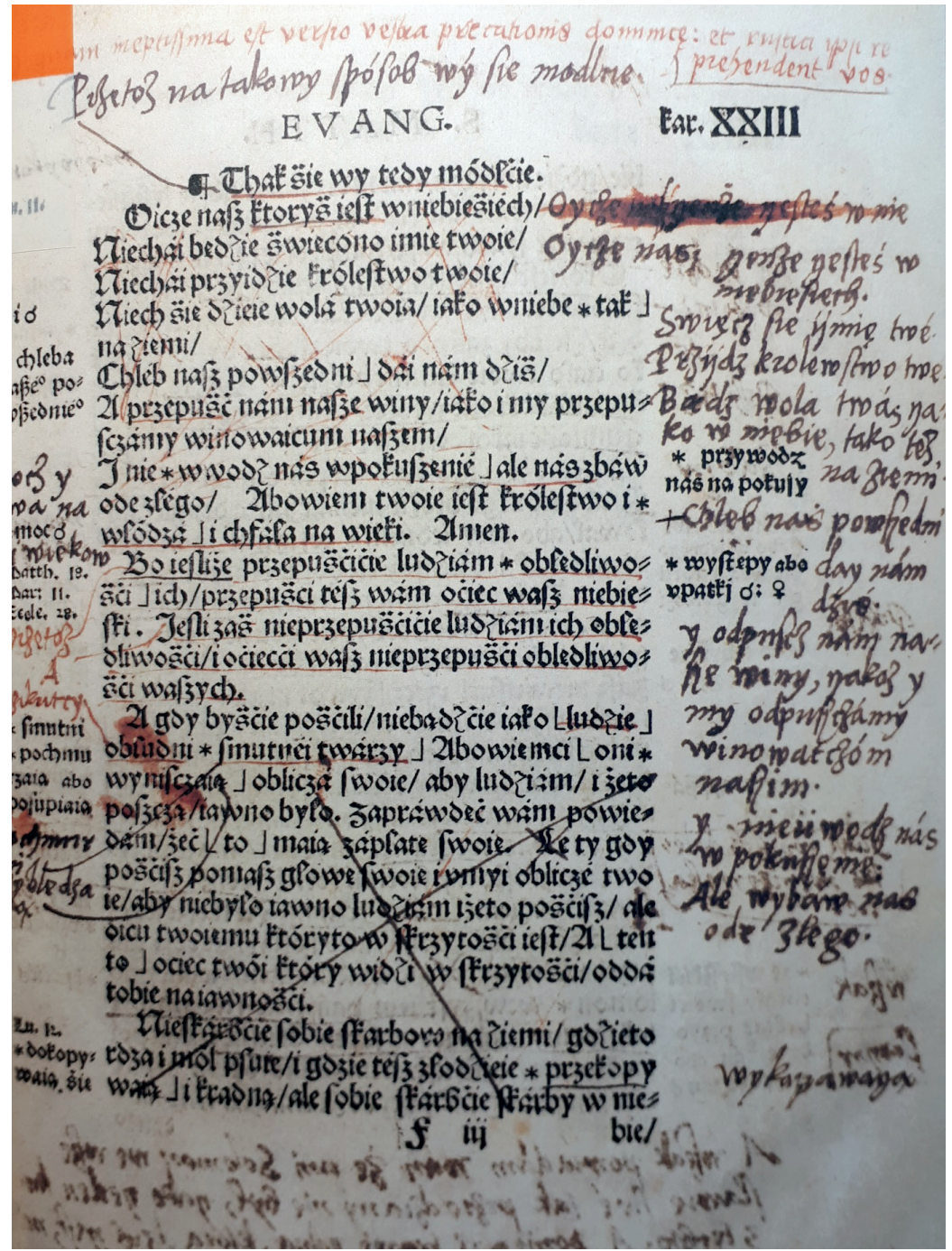

„Ewangelia Święta Pana Jezusa Chrystusa wedle Mateusza świętego” (2003, k. Fiii recto [kar. XXIII]). 
Matteusza pt. «Nowy Testament z przełożenia Erasma Roterodamskiego w jęzik polski prawie a własnemi słowy s wielką pilnością przełożony», Ełk 1552 i dopiero teraz wraz z wspomnianą oceną przekładu Seklucjanowego odesłał księciu” (Barycz, 1962, s. 75-76).

Tym bardziej warto przyjrzeć się owym uwagom, zwłaszcza że dotyczą one trzech języków: greckiego, łacińskiego oraz polskiego. Poprawki i komentarze już na poziomie odczytania sprawiają wiele kłopotu. Ale szczegółowa lektura dzieła nasuwa ciekawe spostrzeżenia.

Lp. Murzynowski

Sandecki-Malecki

Komentarz

Przykład 1: k. Dii verso

V, A gdy uirzał rzesze wszedł

1-2 na gore i przystąpili k'niemu (gdy on usiadł) uczniowie iego. A [on] otworzywszy usta swoie uczył ie mowiąc
A gdy widział rzesze wstąpił Korekta jest nieco zaskakująca, bona gorę: a gdy się posadził, wiem odwołuje się do form bądź przystąpili kniemu uczniowie dziś traktowanych jako oboczne, yego: a gdy otworzył usta swe, bądź już w XVI wieku przestarzałe ucził ye rzekąc (?): (bądź w najlepszym wypadku o charakterze lokalnym)

Przykład 2: k. Fiii recto (kar. XXIII)

VI Thak się wy tedy módlcie.

Oicze nasz któryś iest wniebiesiech /

Niechaj będzie świecono imię twoie /

Niechaj przyidzie królestwo twoie /

Niech się dzieje wola twoia / iako wniebie * tak na ziemi / Chleb nasz powszedni dai nam dziś /

A przepuść nam nasze winy / iako i my przepusczamy winowaicum naszem / I nie * wwodz nas wpokuszenie ale nas zbaw ode złego / Abowiem twoie iest królestwo i * włódza i chfała na wieki. Amen
Przetoz na takowy spósob wy się modlcie.

Oycze nasz yenże yesteś w niebiesiech.

Święcz się ijmie twoe.

Przijdz krolewstwo twoe.

Bądz wola twoa yako w niebie, tako tez na ziemi. + Chleb nasz powszedni day nam dziś.

Y odpuszcz nam nasze winy, Yako y my odpuszczamy winowaiczom naszym.

Y nieii (?) wodz nas w pokuszenie.

Ale wybaw nas ode złego. Mocz y sława na wieki wiekow[.]
Wyraźnie widać tu, iż forma gramatyczna przyjęta przez komentatora ma charakter bardziej archaiczny bądź nosi wyraźnie cechy lokalne. Uderzające jest konsekwentne posługiwanie się np. „y" zamiast „",", "ij" zamiast „y", pojawia się forma "cz" zamiast „c"; takíe w obu tłumaczeniach tłumacze piszą „"t" zamiast "T". Zaskakuje forma "chfała”, która sugeruje inną wymowę „w" w połączeniu z "ch" - czyżby zapis wymowy? Interesujące są formy: "wwodz" bądź "nieii (?) wodz". W obu wypadkach mamy do czynienia z formami, jednak chyba już w XVI wieku nieco archaicznymi. Zastanawia także forma "yenze yesteś" zamiast „któryś iest”. 
Te dwa przykłady pokazują, iż kwestia oceny samego przekładu i komentarza do niego nie jest - z perspektywy naszej dzisiejszej wiedzy o historii języka polskiego - prosta i jednak wymaga nowego namysłu mimo wspomnianego wcześniej dość bogatego stanu badań. Warto zacytować uwagę współczesnego badacza:

Po ukazaniu się Mt wystąpił ze swoją krytyką Malecki, wnosząc własnoręcznie do tekstu niezliczoną ilość poprawek, które wraz z listem przesłał Albrechtowi. Krytyka Maleckiego była tendencyjna i przesiąknięta osobistą niechęcią do konkurenta. Większość uwag była chybiona i niesłuszna. Krytyka nie odniosła jednak skutku, a Seklucjan zachęcony triumfem nad przeciwnikami kontynuował pracę (Pietkiewicz, 2002, s. 198).

Mimo że uwaga ta jest poparta solidną analizą literatury przedmiotu, to jednak wydaje się, iż kwestia nie jest tak prosta i wymaga ponownego opisu oraz analizy. Zwłaszcza z tego powodu, iż uwagi na temat Maleckiego nie mają charakteru merytorycznego, a są wybitnie emocjonalne.

\section{Ewangelia wg św. Mateusza wg Stanisława Murzynowskiego - opis ${ }^{3}$}

Przyjrzeć się trzeba organizacji książki Murzynowskiego. Składa się ona z następujących części:

Tytuł: EVANGE//LIA SVVIETA // PANA IESVSA CHRISTUSA // Vedle Matthaeusza Svietego / z Greckiego // Iezyka na Polski przełozona [...]

Na k. $A^{1}$ verso-Aii recto jest łacińska dedykacja Jana Seklucjana dla księcia Albrechta

Na k. $A^{\text {ii }}$ verso-B $B^{\text {i }}$ verso wstęp Jana Seklucjana: „Swoim wiernem słuchaczom // a słowa bożego prawdziwym miło=//snikum [?!]...”

Na k. B $\mathrm{B}^{\mathrm{ii}}$ recto-Bii verso jest: „ORTHOGRAPHIA // Polska [autorstwa Stanisława Murzynowskiego]”.

Na k. B B $^{\text {iv }}$ recto-B ${ }^{\text {iv }}$ verso są: „Omylności druku... oraz DE AVTORITATE VERBI DEI...”

3 Oryginał opisał Pietkiewicz (2002, s. 194-207). W niniejszym opracowaniu opieram się na reprincie i opis jego dotyczy. 
Na k. A $\mathrm{A}^{\mathrm{j}}$ recto-Biii recto: „Regestr potrzebniejszych rzeczy // które się krotce zamykaią przy Texcie abo wwy//kładzie każdego z osobna Capitulum Euangeljiei we=//dle Mattheusza świętego...”

Na k. Biii verso-B ${ }^{\text {iv }}$ recto znajduje się: „Wykład znakow ktoresie miedzy textem abo // na stronach przy texcie naiduią [.]"

Na k. Biv verso znajduje się wiersz: „AD LATINUM POLONICI // SCRIPTI LECTOREM”

Na k. I-CXXI verso jest zamieszczona Ewangelia wg św. Mateusza wraz z komentarzem po każdym rozdziale oraz notami na marginesach.

Na k. CXXI verso oraz k. nlb. recto jest zamieszczony tekst: „O bluźnierstwie przeciwko duchowi // Swiętemu”.

K. nlb. verso czysta.

Egzemplarz, którym się posługuję, ma pieczątki: na karcie tytułowej pieczątka okrągła z orłem dwugłowym i napisem w języku rosyjskim Biblioteka Warszawskogo Uniwersiteta, na jej odwrocie - pieczątka okrągła z napisem „BUW” i w otoku „Biblioteka Uniwersytecka w Warszawie”, na k. $A^{\text {ii }}$ recto elipsoidalna pieczątka z napisem: „Biblioteka Główna w Warszawie” oraz na końcu pieczątka okrągła „BUW” (Biblioteka Uniwersytetu Warszawskiego).

Jest to reprint wykonany w Białymstoku na zlecenie Towarzystwa Naukowego Płockiego, oprawa współczesna. Na końcu nota wydawnicza podpisana przez Zbigniewa Chlewińskiego oraz dodana informacja na temat sponsorów wydania (Orlen, Kościół Ewangelicko-Augsburski w Polsce, Starostwo Powiatowe w Płocku, Urząd Miasta Płocka, Urząd Gminy Brudzeń).

Prawie wszystkie karty noszą uwagi wpisane ręką Jana SandeckiegoMaleckiego dwoma kolorami atramentu: czerwonym i czarnym w językach: łacińskim oraz polskim (uwag odwołujących się do oryginału greckiego nie ma).

\section{Problemy językowe - wstępny rejestr problemów badawczych}

Kwestie językowe wstępnie są opisane przez Rosponda (1949), Mayenową (1955), Kossowską (1968), Klemensiewicza (1974) i podsumowane przez 
Lenartowicz-Zagrodną (2011). Zwrócono uwagę, że zwłaszcza jeśli chodzi o korektę Maleckiego, to wysuwa on jako kryterium poprawnościowe „normy języka czeskiego, tradycję literacką małopolską, tradycję języka pisanego. Jest zwolennikiem archaizmów i czechizmów, walczy z latynizmami i wyrazami zaczerpniętymi z mowy potocznej” (Mayenowa 1955, s. 72), mimo że od dość dawna to właśnie opinia Mayenowej (1955) jest według mnie najtrafniejsza. Pragnę podkreślić, że uwagi innych badaczy dotyczą ogólnie dyskusji związanej z kształtowaniem się normy językowej. Omówienie całości zagadnień, które nasuwa korekta przekładu Murzynowskiego dokonana przez Sandeckiego-Maleckiego w świetle istniejących badań, uważam w tej chwili za niepotrzebne. Dlatego skupię się tylko na problemach, które nasuwa przykład 3, czyli dwie wersje Modlitwy Pańskiej. Odwołam się do oryginału greckiego, a nie do tłumaczenia łacińskiego, bowiem tłumaczenie to uznaję za wtórne, a ponadto obaj tłumacze - przynajmniej formalnie - wskazują na język grecki jako podstawę tłumaczenia ${ }^{4}$.

Nim przejdę dalej, jeszcze jedna uwaga: w swej Ortografii Murzynowski rozróżnia pomiędzy „f” oraz „W”; niestety, nie podaje przykładów połączenia „chw...” lub „chf...”, zatem można przyjąć, iż przywołany przykład nie jest pomyłką, a świadomym zapisem ${ }^{5}$.

Dalsze uwagi przeprowadzę, odwołując się tylko do Modlitwy Pańskiej. Jak wiemy, dysponujemy tekstem oryginalnym w języku greckim $^{6}$ oraz tłumaczeniami na łacinę i hebrajski ${ }^{7}$. Przypominam te oczy-

4 Należy jednak dodać, iż część uwag Sandeckiego-Maleckiego jest zrobiona w języku łacińskim, m.in. na karcie tytułowej.

5 Kwestię tę wyjaśnia za Taszyckim (1947) Wróbel (2003, s. 7): „ubezdźwięcznienie się spółgłoski $w$ i przejście $\mathrm{w} f \mathrm{w}$ pierwotnej grupie spółgłoskowej chw (a następnie zanik spółgłoski c/i). Mamy więc zapisy: chfycić, chfala, filka itp. Etymologiczna, znormalizowana pisownia uniemożliwia obserwację tego typu upodobnień”. Dla naszych rozważań ważne jest to, że tego typu ubezdźwięcznienie nie zaszło wcześnie jedynie właśnie w Wielkopolsce w odróżnieniu od Mazowsza i Małopolski (por. Taszycki 1947, s. 40).

6 Sugestia, iż zachował się tekst w aramejskim, to tylko domniemanie; niestety, jest to też tłumaczenie (por. Flis 2013, s. 21-41).

7 Tłumaczenia na inne języki nie są i nie będą przedmiotem mojego zainteresowania, choć być może warto wziąć ewentualnie pod uwagę tłumaczenie na starocerkiewnosłowiański: Отьчє нашь· ижє єси на нєбєсьхъ: да свАтитъ сА имА Твою· да придєтъ цьсарььствиє Твою· да бждєтъ волға Твоға ғако на нєбєси и на зємлй: хльбъ нашь 
wistości, bowiem około 1550 roku polscy bibliści mieli do dyspozycji różne wydania Biblii, w tym edycję Erazma z Rotterdamu oraz tzw. Poliglotę kompluteńską ${ }^{8}$.

Nie będę wchodził w zawiłości interpretacyjne samej Modlitwy Pańskiej, a zajmę się wyłącznie porównaniem polskich wersji językowych z wersją grecką.

\begin{tabular}{|c|c|c|c|}
\hline & Tekst grecki & Murzynowski & Sandecki-Malecki \\
\hline 0 & 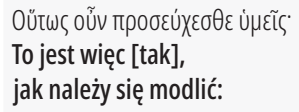 & Thak się wy tedy módlcie. & $\begin{array}{l}\text { Przetoz na takowy spósob } \\
\text { wy się modlcie. }\end{array}$ \\
\hline $1^{9}$ & 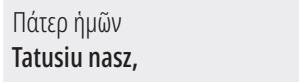 & Oicze nasz & Oycze nasz \\
\hline 2 & $\begin{array}{l}\text { ó ÉV โ⿳亠̃ oủpavũ / } \\
\text { w niebiosach, }\end{array}$ & któryś iest wniebiesiech / & yenże yesteś w niebiesiech. \\
\hline 3 & 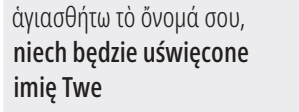 & $\begin{array}{l}\text { Niechaj będzie świecono imię } \\
\text { twoie / }\end{array}$ & Święcz się ijmie twoe. \\
\hline 4 & 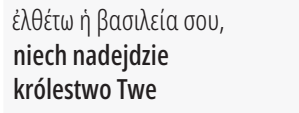 & $\begin{array}{l}\text { Niechaj przyidzie królestwo } \\
\text { twoie / }\end{array}$ & Przijdz krolewstwo twoe. \\
\hline $\begin{array}{l}5 \\
6\end{array}$ & 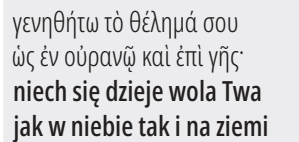 & $\begin{array}{l}\text { Niech się dzieje wola twoia / } \\
\text { iako wniebie*tak na ziemi / }\end{array}$ & $\begin{array}{l}\text { Bądz wola twoa yako } \\
\text { w niebie, tako tez na ziemi. }\end{array}$ \\
\hline
\end{tabular}

насжщьныи даждь намъ дьньсь и отъпоусти намъ длъгы нашА ғако и мы отъпоущаюмъ длъжьникомъ нашимъ- и нє въвєди насъ въ искоушєнию· нъ избави ны отъ нєприғазни: ғако твою юстъ цьсарিьствию и сила и слава въ вђкы вькомъ Аминь.

8 Mam na myśli wydania: J. Frobena (1) z roku 1516, (2) z roku 1519, (3) z roku 1522, (4 i 5) z lat 1527 i 1535 (por. Jańczuk, 2014, s. 27-40); także dawna ale ważna praca Tregellsa (1854, s. 19-29). Natomiast tzw. poliglota kompluteńska ukazała się w latach 1514-1517 (opis wydania: Trypućko et al. 2007, s. 1235), a następnie ponownie w roku 1522.

9 Przekład polski za Flisem (2013), wers 0 w moim przekładzie. 
Tekst grecki

Murzynowski

Sandecki-Malecki

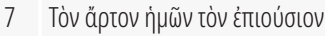

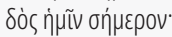

chleba naszego powszedniego

daj nam dzisiaj

Chleb nasz powszedni

+ Chleb nasz powszedni

dai nam dziś /

day nam dziś.

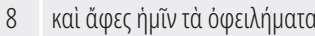

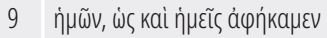

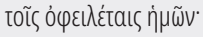

i przebacz nam winy nasze,

jak i my odpuściliśmy

winnym nam

A przepuść nam nasze winy / iako i my przepusczamy winowaicum naszem/
Y odpuszcz nam nasze winy, Yako y my odpuszczamy winowaiczom naszym.

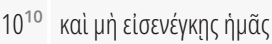

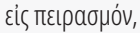

i nie stawiaj nas wobec próby i nie prowadź nas do próby

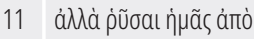
toũ rovпроũ.

ale wyrwij nas od złego

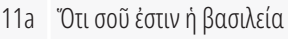

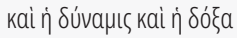
દis toũs aī̃vas. bo Twoja jest moc i chwała na wieki

\begin{abstract}
/ Abowiem twoie iest królestwo Mocz y sława
i * włódza i chfała ${ }^{11}$ na wieki. na wieki wiekow[.]
\end{abstract}

12 Apŕv. Amen

Pierwsza uwaga, która się nasuwa, to że w zasadzie oba tłumaczenia są poprawne. Różnice nie dotyczą zatem rozumienia tekstu greckiego,

10 Są dwa warianty rozumienia, drugi wiąże się z Didache. Ale tradycja hebrajska dopuszcza tylko następujące znaczenie: „i nie dopuść, abyśmy ulegli pokusie” (por. „Christentum und Judentum. Parallelen”, 1906, s. 85; Zolli, 2015, s. 110-111, 107-119, 277-298). W przywołanych w przypisie 1 Statuta synodalia episcoporum Wratislaviensium z 1457 wers ten brzmi: „Ee nyewodzy nasz napokusszynye” (por. Masłej, 2016, s. 64). Problemem jest oczywiście użyty tu czasownik „wodzić” (por. Boryś, 2008, s. 706): znaczy m.in. „prowadzić”, ale związane z „wieść” (Boryś, 2008, s. 697): znaczy m.in. „odwodzić” [sic!]. Podobnie Brückner (1985, s. 619): „wieść” (tu uwaga na temat stosowania podwojonego „W”). Jednakże zakres znaczeniowy „pokuszenie” (od „pokusa”, por. Boryś 2008, s. 458): znaczy m.in. „próba”, „poddać próbie”.

11 To może być wynik upodobnienia w wymowie - bezdźwięczne „ch” wpłynęło na wymowę „W” jako „f”. 
ale różnią się wyłącznie w zakresie języka polskiego. Zwracam uwagę, że wers 11a pojawia się także w wersji Didache 8, 2 (3) ${ }^{12}$. Interesujące jest, że wersja z roku $1923 \mathrm{w}$ zasadzie jest zgodna z tłumaczeniami Murzynowskiego i Sandeckiego-Maleckiego.

Bardzo interesująca jest konsekwencja, z jaką Sandecki-Malecki posługuje się formą „twoa” / „twoe”, a także wspomniana kwestia ubezdźwięcznienia się spółgłoski „w” i jej przejście w „„”, co może się wiązać z wpływem języka mówionego na wersję drukowaną.

Jeśli chodzi o wersy 3-6, to, jak sądzę, Malecki jest bliższy oryginałowi; wersja Murzynowskiego jest natomiast o tyle bardziej poprawna po polsku, że wprowadza bardzo piękną anaforę dla form trybu rozkazującego: „niech(aj)”. Malecki posługuje się jednak także dopuszczalną formą tegoż samego trybu.

Nie ma natomiast wątpliwości, że nawet w tak krótkim tekście Malecki posługuje się formami bądź gwarowymi, bądź archaicznymi. Najlepszym przykładem jest wers 2, gdzie zamiast formy „któryś iest” wprowadza formę „yenże yesteś”, która choć dopuszczalna zapewne w połowie wieku XVI, musiała brzmieć nieco niezrozumiale ${ }^{13}$. Jednak Malecki bronił swego stanowiska w Defensio verae translationis corporis Catechismi (1547), w którym to dziełku wyjaśniał też pewne rozwiązania translatorskie zastosowane m.in. w ostrym komentarzu do tłumaczenia Murzynowskiego (Lenartowicz-Zagrodna, 2011, s. 124-125):

Lecz być może powiadasz: te słowa yenż i yenże są już przestarzałe. Wręcz przeciwnie, aprobowane są nieustannie od owego czasu aż do naszego wieku. W przeciwnym bowiem razie tego wersu nie śpiewałoby się w naszym wieku.

12 „Ojcze Nasz, który jesteś w niebiesiech, święć się Imię Twoje, przyjdź Królestwo Twoje, bądź Wola Twoja, jako w niebie, tak i na ziemi; chleba naszego powszedniego daj nam dzisiaj, i odpuść nam naszą winę, jako i my odpuszczamy naszym winowajcom, i nie wwódź nas na pokuszenie, ale nas zbaw ode złego; albowiem Twoja jest moc i chwała na wieki” („Didache, czyli nauka dwunastu Apostołów”, 1923, s. 23, podkreślenie własne). W wersji opracowanej przez Davida Roberta Palmera w 2017 roku także jest ten fragment (http://bibletranslation.ws/trans/mattwgrk.pdf, 05.07.2019).

13

Wiązać to można także z faktem, iż Bogurodzica, którą przedrukowuje Jan Łaski w swym dziele prawnym, była jednak daleko bardziej popularna, niż nam się dzisiaj wydaje (por. Łaski, 1506). 
Masz również te słowa yenż, yenże i yenżes zapisane w wielu miejscach polskojęzycznego Raju dusznego, którą to książeczkę, bajki Ezopa wierszem oraz inne liczne przełożył na język polski w naszym wieku pierwszy autor polskich książek, Biernat z Lublina, mąż bardzo uczony i bardzo biegły w polszczyźnie, sekretarz pana Jana z Pilicy. Tenże Biernat z Lublina, mąż biegły w języku czeskim, a bardzo biegły w polskim, wiedział, że ów zaimek qui w znaczeniu względnym należy przetłumaczyć przez yenż lub yenże, natomiast qui w znaczeniu pytajnym należy przetłumaczyć przez ktory. Masz nade wszystko to słowo yenże użyte w Modlitwie Pańskiej, w owym Raju dusznym, wydrukowanym w Krakowie. Znajdziesz zaś tę modlitwę zamieszczoną w rzeczonym Raju dusznym na samym początku. Masz również w owym Raju dusznym to słowo yenż, użyte w napisanym przez świętego Chryzostoma poświęceniu stołu, zaczynającym się od słów: Benedictus Deus, qui me pascis - Błogosławiony Boże, yenż mię pasies etc., a zamieszczonym po Modlitwie Pańskiej (podkreślenia własne).

A zatem rozróżnienie pomiędzy zaimkami „który” oraz „yenż” i „yenże” nie jest wyrazem zamiłowania do archaizmów, ale rozróżnieniem pomiędzy znaczeniami słów (w tym wypadku zaimków) w zależności od tego, jak są użyte: czy jako pytanie, czy jako określenie np. okoliczności (por. Doroszewski \& Wieczorkiewicz, 1959, s. 83-92; Wieczorkiewicz \& Sinielnikoff, 1965, s. 105). Zwracam uwagę, iż dziś takie rozróżnienie wygląda na całkowicie sztuczne, współczesne rozumienie jest następujące (Doroszewski \& Wieczorkiewicz, 1959, s. 83-92):

zaimek „który” służy do zadania pytania lub do określenia w zdaniu podrzędnym elementu (osoby, rzeczy, zwierzęcia, pojęcia itd.) z pewnej grupy elementów. Odpowiedź na pytanie „który” może być również wyrażona za pomocą liczebnika porządkowego lub przymiotnika. W niektórych sytuacjach może być stosowany zamiennie z zaimkami „kto” i „co”. Dodatkowo, zaimek względny może być użyty w zdaniu podrzędnym, które rozwija treść ze zdania głównego.

Jednak w teorii retoryki, gdy mówimy o okolicznościach sprawy (perystaseis), kwestia ta nie wygląda tak prosto. Wydaje się, że Małecki pragnie rozróżnić sytuację, gdy pytamy o kogoś lub o coś, od sytuacji, gdy podajemy np. określenie, gdzie ktoś lub coś się znajduje (czyli chodzi o „zaimek pierwotnie wskazujący”). Małecki ma tu bezwzględnie 
rację - jak notuje w swym słowniku Forcellini - zaimek „qui” jest używany jako: (1) relativum, (2) interrogativum, (3) indefinitum. To, że obecnie przyjęliśmy konwencję tłumaczenia z reguły „qui” jako „który” (czyli jako zaimek względny, a nie wskazujący), nie było oczywiste w wieku XVI (por. Forcellini, 1965, s. 1011-1013; Wieczorkiewicz \& Sinielnikoff, 1965, s. 103-107).

Ważne jest wyjaśnienie samego Maleckiego co do wprowadzenia tegoż słowa właśnie w Modlitwie Pańskiej (Lenartowicz-Zagrodna, 2011, s. 133-134):

pan Seklucjan bezsprzecznie nie popełnił błędu, jako że to słowo chleba jest również biernikiem. Pan Seklucjan zdaje się nie wie tego, że ów rzeczownik chleb ma dwojaki biernik, mianowicie chleb i chleba. Mówimy bowiem po polsku: day mi ten chleb i mówimy: day mi tego chleba, co po łacinie mówi się da mihi hunc panem. Co więcej, w Modlitwie Pańskiej ów biernik chleb pozostaje w powszechnym użyciu wśród ludu. Z racji tego w Modlitwie Pańskiej należy użyć tego biernika, który już znajduje się w użyciu, nie zaś wprowadzać w zamieszanie proste dusze zamianą w nauczaniu [jednego] biernika na [drugi] biernik, bez żadnej konieczności. Co więcej, zgodnie ze wskazówką muzyczną należy mówić i śpiewać chleb nasz, bowiem chleba naszego nie może zmieścić się w czasie trwania nuty ${ }^{14}$. Masz zatem biernik w tej postaci chleb, którą i ty zapisałeś w twoim katechizmie, wykorzystany w słowach Wieczerzy [Pańskiej] tak oto: wziąt chleb - to jest accepit panem. Ponadto w owym czeskim Nowym Testamencie ten fragment panem nostrum przełożono tak oto: chleb nasz wezdeiszi etc.; do tego czeskiego tłumaczenia winno się odnosić wszystkie.

A zatem chodzi tu o dwie kwestie: po pierwsze, o sposób wymawiania słów (wzmianka o muzyce), po drugie, wskazuje na skomplikowaną sprawę, którą jest ta sama forma rzeczownika w mianowniku i bierniku. Sądzę, że Malecki ma rację. Zwracam uwagę, że wers 7 jest w obu tłumaczeniach identyczny ${ }^{15}$. Lenartowicz-Zagrodna (2011, s. 109) ma również rację, gdy pisze:

14 Jest to ważna uwaga, która może nawiązywać do tradycji melorecytacji w tradycji judaistycznej, szerzej na ten temat m.in. Zolli (2015, 47-50).

15 To raczej my się mylimy - ale o tych kwestiach nie będę się wypowiadał. 
w kontekście przytoczonych przykładów Malecki jawi się jako zaciekły purysta, archaizator i zwolennik monumentalnego stylu oraz czeszczyzny, przeciwnik języka potocznego. Takie podejście wynikało z jego zapatrzenia w średniowieczną, dostojną i książkową polszczyznę, wyrosłą na gruncie tekstów religijnych, zwłaszcza psałterzowych, których pierwsi twórcy korzystali z osiągnięć czeskich tłumaczy Biblii. Był on jednocześnie redaktorem bardzo konsekwentnym, doświadczonym i świadomie stosującym opracowany przez siebie system. Seklucjan przeciwnie [...], z jego wydań przebija brak doświadczenia, który skutkuje graficznym niechlujstwem i chaotyczną konstrukcją zdań.

A zatem polemika ta dotyczy języka, którym winna być tłumaczona Biblia. Można powiedzieć, że jest to pierwszy, ale nie ostatni spór o wybór języka, którym będziemy mówić o problemach religii.

Należy też pamiętać o fakcie, który omówił Adam Wróbel (2003, s. 5) - wskazywał on na cechy regionalne i dialekt dobrzyński, który bez trudu odnajdziemy także w omawianym tłumaczeniu:

Stanisław Murzynowski dał nam taką potoczystą piękną prozę zbliżoną do języka codziennego, nie krępowaną językiem książkowym. Przy czym, co musimy wyraźnie podkreślić, dla naszych rozważań bardzo ważne jest właśnie to, że utalentowany, choć bardzo młody pisarz, nasycił swoje tłumaczenie Nowego Testamentu językiem stron rodzinnych, nie krępując się archaicznymi formami rękopiśmiennego tłumaczenia Pisma Świętego, które to archaizmy poumieszczał w glosach.

Przytaczam tę opinię, aby tym silniej podkreślić, że kwestia posłużenia się językiem potocznym, a zarazem osadzonym w dialekcie i zawierającym cechy regionalne spowodowała tak ostrą polemikę. Przytaczana wcześniej opinia Lenartowicz-Zagrodnej (2011) w pełni przyczynę tejże polemiki potwierdza.

W jakiejś mierze spór ten zamknął przekład Jakuba Wujka - ale de facto nie na długo. 


\section{Dyskusja}

Patrząc krytycznie na to, co zostało wyżej powiedziane, trzeba wskazać trop, który początkowo zamierzałem odłożyć. Chodzi o przekład Modlitwy Pańskiej najęzyk starocerkiewnosłowiański. Spójrzmy teraz na tę kwestię:

\section{\begin{tabular}{l|l|l}
\hline Tekst grecki & Starocerkiewnosłowiański & Sandecki-Malecki
\end{tabular}}

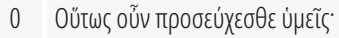

To jest więc [tak], jak należy się modlić:

Przetoz na takowy spósob wy się modlcie.

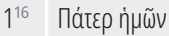

Tatusiu nasz,

Oćcze naś,

Oycze nasz

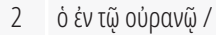

w niebiosach,

iże jesi na niebiesǐch,

yenże yesteś w niebiesiech.

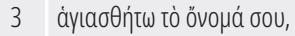
niech będzie uświęcone imię Twe

da świętit się imię twoje, Święcz się ijmie twoe.

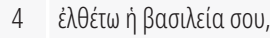
niech nadejdzie królestwo Twe da priidziet cěsarzstwo twoje, Przijdz krolewstwo twoe.

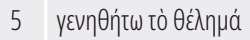

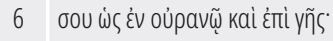
niech się dzieje wola Twa jak w niebie tak i na ziemi

da bądziet wola twoja na zemli jako na niebiesi;
Bądz wola twoa yako w niebie, tako tez na ziemi.

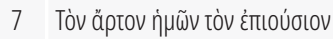

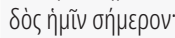

chleba naszego powszedniego

daj nam dzisiaj

chlěb naszi nasąśnyj

dażdź nam w dzin semĭ,

+ Chleb nasz powszedni

day nam dziś.

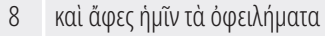

9 ท்

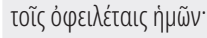

i przebacz nam winy nasze,

jak i my odpuściliśmy

i ostawi namĭ dłŭgy nasi

jako i my ostawlajemŭ

winnym nam

Y odpuszcz nam nasze winy, Yako y my odpuszczamy winowaiczom naszym.

16 Przekład polski za Flisem (2013); wers 0 w moim przekładzie. 


\begin{tabular}{|c|c|c|c|}
\hline & Tekst grecki & Starocerkiewnosłowiański & Sandecki-Malecki \\
\hline 10 & 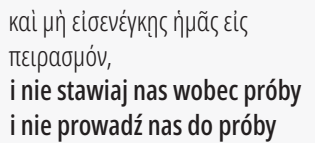 & ne wŭwedi nas w napaśćc ${ }^{17}$ & $\begin{array}{l}\text { Y nieii (?) wodz nas } \\
\text { w pokuszenie. }\end{array}$ \\
\hline 11 & 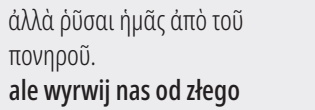 & i izbawi nas ot neprijĕzni. & Ale wybaw nas ode złego. \\
\hline $11 \mathrm{a}$ & 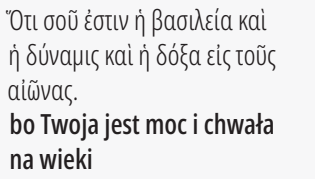 & $\begin{array}{l}\text { Twoje bo jest cĕsarzstwo i siła } \\
\text { i sława na wĕky. }\end{array}$ & $\begin{array}{l}\text { Mocz y sława } \\
\text { na wieki wiekow [.] }\end{array}$ \\
\hline 12 & Ани́v. & Amiń. & \\
\hline
\end{tabular}

Zestawienie to dobitnie pokazuje, iż chyba jednak obaj tłumacze znali tę wersję; co więcej - bliższa ona była, jak mniemam, Maleckiemu niż Murzynowskiemu. Co więcej, dla Maleckiego musiała mieć walor dodatkowy tradycji, stąd posłużenie się słowami, które w połowie XVI wieku były jednak traktowane jako bądź archaiczne, bądź mało zrozumiałe dla ogółu wiernych.

Jak wiemy z gramatyki historycznej języka polskiego zaimek „yenż” i „yenże” ukształtował się z:

[z]aimka pierwotnie wskazującego on, ona, ono [...] forma dawna ji, ja, je [...] zachowały się $\mathrm{w}$ formach: $j i+\dot{z} e, j a+\dot{z} e, j e+\dot{z} e$ a rodzaj męski spotyka się również w postaci jenże, jenż. [...] Formy te mają jednak znaczenie zaimka względnego, tak samo jak dziś zaimek który, -a, -e (Wieczorkiewicz \& Sinielnikoff 1965, s. 105, podkreślenia własne).

Czyli wers 2 mógł brzmieć: „*ji jesi” (notowana jest forma starocerkiewnosłowiańska: „iże jesi”), forma ta, poprawna ale nie notowana, ma tylko „tradycję” w Maleckiego „yenże yesteś”. Jest zatem

17 Tłumaczenie Murzynowskiego: „I nie * wwodz nas wpokuszenie”, co sugerowałoby, iż obaj tłumacze znali tę wersję. 
szalenie ważnym zapisem formy - być może archaicznej w połowie wieku XVI - ale ważnej i poprawnej gramatycznie. Ale ważna jest uwaga Wieczorkiewicza \& Sinielnikoff (1965), że oto „zaimek pierwotnie wskazujący” miał także „znaczenie zaimka względnego”, czyli u Maleckiego mamy ostatni ślad rozróżnienia znaczeń tegoż zaimka (por. Lenartowicz-Zagrodna, 2011, s. 124-125). Jak sądzę, acz jest to już tylko kwestia historyczna, to zarazem dotykamy tu momentu zaniku w języku polskim pewnych form gramatycznych: tu zaimka wskazującego i łączenia się jego znaczenia z zaimkiem względnym. Kwestia pozornie błaha, a jednak jest to ślad upraszczania się form językowych. Zarazem - tu kryją się możliwości nieporozumień w zakresie znaczenia słów i zdań. To jednak inna kwestia, którą tylko sygnalizuję.

\section{Ekskurs nt. tłumaczenia wersetu 10 w Modlitwie Pańskiej (Łk 11, 4; Mt 6, 13) ${ }^{18}$}

W tłumaczeniu Jakuba Wujka ten werset brzmi: „nie wwódź nas w pokuszenie”. A zatem problem mamy z wyrażeniami: „wwodzić w” oraz „pokuszenie”. Przywołane wcześniej rozważania oparte na hasłach ze słowników Wiesława Borysia i Aleksandra Brücknera potwierdza zapis ze słownika Mariana Arcta. Powiada on wyraźnie: „nie wwódź nas $(\mathrm{w})$ na pokuszenie = nie pozwól nam ulegać pokusom” (Arct, 1916, s. 332-333). Słownik rosyjsko-polski podaje (dzisiejsze) znaczenia słowa „Vvesti”, które oznacza m.in. „wprowadzić w”, „zapoznać z(e)...”, ale też „narazić na...”. Słowo zaś „pokusit’sja” oznacza m.in. „sięgnąć po cudzą własność" (Mirowicz, 1980a, s. 89-90; Mirowicz, 1980b, s. 903) ${ }^{19}$. We współczesnych zatem znaczeniach wskazanych słów możemy bez trudu odczytać dawne znaczenia, tym bardziej że wyraźnie tak właśnie, jak wskazałem, można je rozumieć. Oczywiście, pewnym problemem może być, iż byłyby to rusycyzmy. Jak sądzę - jest to błędne rozumowanie, bowiem znaczenia te przypisuję i wiążę z tradycją bądź staropolską,

18 Por. Flis 2013, s. 21-41.

19 Jak sądzę, podane znaczenia mają silną tradycję historyczną. 
bądź starszą, starocerkiewnosłowiańską. A zatem to my, niestety, przyjęliśmy błędną lekcję wersetu 10 Modlitwy Pańskiej ${ }^{20}$.

Za takim wnioskiem może też przemawiać fakt, iż lektura słownika Knapiusza przynosi spore zaskoczenie. Oto oczywiście obydwa słowa są w nim odnotowane, jednak ich znaczenia są, delikatnie mówiąc, nieco inne od spodziewanych. Słowo „pokuszenie” znaczy invitamentum [zachęta, ponęta. powab] (Knapiusz 1787b, s. 367); słowo „wwodzić” znaczy od „wprowadzam” [„,kogo albo co” - introduco; „się gdzie” immigro] lub jest pojęciem prawniczym „wwodzę co w księgi prawne” (Knapiusz 1787c, s. 433, 417). Jesteśmy zatem w sytuacji dość niezręcznej; albo nasi przodkowie modlili się po łacinie, albo posługiwali się pojęciami w języku polskim dla nich tak oczywistymi, iż nie musieli ich objaśniać w słownikach ${ }^{21}$.

Jednak - co też trzeba odnotować - w kancjonałach pojawia się lekcja „nie wódź nas na pokuszenie” - tak odnotowują wydania z XVIII wieku i z wieku XX (por. „Nowo wydany Kancyonał Pruski...”, 1741, s. 368; Bursche et al., 1905, s. 264).

Warto zauważyć wreszcie, że tzw. Biblia Tysiąclecia od wydania z roku 1965 werset ten tłumaczy w brzmieniu: „nie dopuść, byśmy ulegli pokusie”. Natomiast, co jest zaskakujące, Biblia w przekładzie Brytyjskiego i Zagranicznego Towarzystwa Biblijnego (np. w wydaniu z roku 1975), werset ten tłumaczy: „nie wódź nas na pokuszenie”. Identycznie jest to tłumaczone w Mszale z czytaniami w opracowaniu Loski (1999, s. 711). Tej ostatniej wersji bronią m.in. ks. Czesław Bartnik oraz ks. Wojciech Węgrzyniak - z odwołaniami do tradycji staropolskiej (sic!) oraz greckiej i łacińskiej (por. Bartnik, 2018 z błędnym, a na pewno dyskusyjnym odwołaniem do języka starocerkiewnosłowiańskiego; Węgrzyniak, 2019, s. 312). Trzeba też wskazać, iż m.in.

20 Przykłady daruję, bowiem jest ich zbyt wiele, włącznie z wersjami, które są używane w liturgii. Jest tym bardziej zaskakujące, że w wersji Wulgaty werset ten brzmi po polsku: „i nie wprowadzaj nas w próby” (et ne nos inducas in temptationem). Użyty tam rzeczownik „temptatio” znaczy „próba, atak (choroby), pokusa”; por. Forcellini (1965, s. 693): „tentatio” vel „temptatio”, z sugestią, iż raczej oznacza to „próbę” lub „wystawianie na próbę” (ze wskazaniem na tłumaczenie Wulgaty, np. Wj 17, 7).

21 Co jest założeniem szalenie ryzykownym. 
w podręczniku do nauki religii z 1957 roku werset 10 Modlitwy Pańskiej brzmi: „I nie wódź nas na pokuszenie” (por. Baranowski \& Noryśkiewicz, 1957, s. 39).

Jak sądzę spór, z którym mamy do czynienia w wypadku wydania seklucjanowego, jest jednak do rozstrzygnięcia. Obaj tłumacze podają prawidłową lekcję tego wersetu. „Wygrana” Murzynowskiego wynika chyba z większej zrozumiałości jego przekładu dla wiernych. Mamy zatem jakby pierwszy sygnał sporu, który pozornie definitywnie rozstrzygnął II Sobór Watykański. A w kwestii brzmienia i rozumienia wersetu 10 musimy przyjąć, iż obie wersje są obecne w tradycji co najmniej od XVI wieku i za posługiwaniem się nimi przemawiają równie silne racje.

\section{Konkluzje}

Czy są możliwe jednoznaczne konkluzje? Wątpię, a przyczyna tego tkwi w sposobie postrzegania czegoś, co można dziś określić jako archaizację. Jeśli jesteśmy zwolennikami modernizacji języka w przekładzie np. Nowego Testamentu, to podejście Murzynowskiego - po eliminacji oczywistych błędów redaktorskich bądź drukarskich - będzie nam bliższe. Jeśli wolimy podejście bardziej tradycyjne - wtedy rozwiązania proponowane przez Maleckiego wydają się trafniejsze. Na uboczu zostawiamy wtedy kwestię czytelności i zrozumiałości przekładu - w tym względzie przekład Murzynowskiego jest bezwzględnie trafniejszy. Malecki jest natomiast przykładem próby znalezienia pomostu pomiędzy tradycją a nowoczesnością. Spór zatem wydaje się nierozstrzygalny, świadczy jednak o tym, że przynajmniej Malecki zasadę sola Sciptura traktował rygorystycznie. Co więcej, jego uwagi zawarte w tekście Defensio verae translationis corporis Catechismi in linguam Polonicam... są niezwykle ważne dla badań nad historią języka polskiego. Sądzę zatem, iż to właśnie Jan Malecki jest w tym sporze postacią daleko bardziej interesującą i ważną niż Murzynowski. Jednak niezależnie od sporu o osoby pozostaje problem, który go wywołał - jak winniśmy tłumaczyć Nowy Testament? I to pytanie pozostanie bez odpowiedzi. 


\section{Abstrakt}

\section{Tłumaczenie - z poprawkami Jana Maleckiego - Ewangelii według św. Mateusza przez Stanisława Murzynowskiego}

Celem przedstawionych badań były opis i analiza poprawek rękopiśmiennych w królewieckiej edycji Ewangelii Świętej Pana Jezusa Chrystusa wedle Mateusza świętego (1551). Tłumaczenia dokonał Stanisław Murzynowski, a poprawki naniósł Jan Sandecki-Malecki. Mimo sporej literatury przedmiotu autor powraca do tego sporu, aby pokazać kształtowanie się języka polskiej biblistyki w połowie wieku XVI. Jest to tym bardziej interesujące, iż zgodnie ze świadectwem Łukasza Górnickiego właśnie tłumaczenie Biblii miało wielkie znaczenie dla rozwoju języka polskiego. Zaprezentowane wyniki są wstępem do szerszych badań tytułowego zagadnienia.

Słowa kluczowe: Stanisław Murzynowski, Jan Sandecki-Malecki, Łukasz Górnicki, Ewangelia św. Mateusza, przekład, analiza językowa

\section{Abstract}

\section{Translation - with amendments by Jan Malecki - of the Gospel according to Saint Matthew according to Stanisław Murzynowski}

The aim of the study is the description and analysis of manuscript corrections in the Königsberg edition of the Gospel according to Saint. Matthew (1551). The translations were made by Stanisław Murzynowski, and Jan Sandecki-Malecki introduced the corrections. Despite the considerable literature on the subject return to this dispute, to show the development of Polish Biblical language in the mid-sixteenth century. This is all the more interesting because, according to the testimony of Łukasz Górnicki, the Bible translation was of great importance for the development of the Polish language. This study is an introduction to broader research on the subject matter.

Keywords: Stanisław Murzynowski, Jan Sandecki-Malecki, Łukasz Górnicki, Gospel according to Matthew, translation, language analysis

\section{References}

Abramowicz, Z., \& Ławski, J. (Eds.). (2009). Chrześcijańskie dziedzictwo duchowe narodów stowiańskich: Vol. 1: Wokót kultur śródziemnomorskich. Literatura i słowo. Trans Humana. 
Abramowicz, Z., \& Ławski, J. (Eds.). (2010). Chrześcijańskie dziedzictwo duchowe narodów słowiańskich: Vol. 2: Wokót kultur śródziemnomorskich. Historia, język, kultura. Trans Humana.

Arct, M. (1916). Słownik ilustrowany języka polskiego (Vol. 3). Wydawnictwo M. Arcta.

Baranowski, Z., \& Noryśkiewicz, J. (1957). Życie religijne. Klasa IV (4th ed.). Księgarnia św. Wojciecha.

Bartnik, C. (2018, January 14). I nie wódź nas na pokuszenie. Nasz Dziennik.

Barycz, H. (1962). Szermierz polskiej książki drukowanej: Jan Sandecki-Malecki. Rocznik Sacdecki, 5, 49-86.

Biblia to jest księgi Starego i Nowego Testamentu według łacińskiego przekładu starego, $w$ kościele powszechnym przyjętego, na polski język znowu z pilnościa przełożone [...] (J. Wujek, Trans.). (1599). Drukarnia Łazarzowa.

Biblia to jest Pismo Święte Starego i Nowego Testamentu. (1975). Brytyjskie i Zagraniczne Towarzystwo Biblijne.

Biliński, A. (1932). Szlachta ziemi dobrzyńskiej za ostatnich Jagiellonów. Studjum historyczno-heraldyczne (Z. Wdowiszewski, Ed.). Wydawnictwo Kasy imienia Mianowskiego Instytutu Popierania Nauki.

Boryś, W. (2008). Stownik etymologiczny języka polskiego. Wydawnictwo Literackie.

Brückner, A. (1906). Dzieje języka polskiego. Wende i Spółka.

Brückner, A. (1985). Słownik etymologiczny języka polskiego. Wiedza Powszechna.

Bursche, J., Holtz, E., Grundlach, R., \& Schultz, E. H. (Eds.). (1905). Śpiewnik dla Kościoła Ewangelicko-Augsburskiego w Polsce. W. Mietke.

Chojnacki, W. (1966). Bibliografia polskich druków ewangelickich ziem zachodnich i pótnocnych 1530-1939. Wydawnictwo Zwiastun.

Christentum und Judentum. Parallelen. (1906). Jahrbuch Des Verbandes Der Vereine Für Jüdische Geschichte Und Literatur.

Didache, czyli nauka dwunastu Apostołów (J. Jankowski, Trans.). (1923). Księgarnia Kuncewicza i Hofmana.

Doroszewski, W., \& Wieczorkiewicz, B. (Eds.). (1959). Gramatyka opisowa języka polskiego z ćwiczeniami: Vol. 2: Fleksja, składnia. Państwowe Zakłady Wydawnictw Szkolnych.

Ewangelia Święta Pana Jezusa Chrystusa wedle Mateusza świętego (S. Murzynowski, Trans.). (2003). Towarzystwo Naukowe Płockie.

Fischer, B., Gribomont, I., Sparks, H. F. D., Thiele, W., \& Weber, R. (Eds.). (1975). Biblia sacra iuxta Vulgatam versionem (2nd ed., Vols. 1-2). Dt. Bibelges.

Flis, J. (2013). Struktura i treść krótszej wersji modlitwy „Ojcze nasz” (Łk 11, 2b-4). Colloquia Theologica Ottoniana, 2, 21-41.

Forcellini, E. (1965). Lexicon totius latinitatis (Vol. 4b). Forni.

Górnicki, Ł. (1961). Dworzanin polski. In R. Pollak (Ed.), Pisma (Vol. 1, pp. 47-454). Państwowy Instytut Wydawniczy. 
Guldon, Z. (1967). Mapy Ziemi Dobrzyńskiej w drugiej połowie XVI w. Podziały administracyjne, rozmieszczenie własności ziemskiej. Towarzystwo Naukowe w Toruniu.

Jańczuk, L. (2014). Novum Instrumentum omne. Rocznik Teologiczny, 56(1), 27-40.

Klemensiewicz, Z. (1974). Historia języka polskiego (2nd ed.). Państwowe Wydawnictwo Naukowe.

Knapiusz, G. (1787a). Stownik polsko-łaciński [...] (B. G. Woronowski, Ed.; Vol. 1). Drukarnia Prymasowska.

Knapiusz, G. (1787b). Stownik polsko-taciński [...] (B. G. Woronowski, Ed.; Vol. 2). Drukarnia Prymasowska.

Knapiusz, G. (1787c). Stownik polsko-taciński [...] (B. G. Woronowski, Ed.; Vol. 3). Drukarnia Prymasowska.

Kossowska, M. (1968). Biblia w języku polskim (Vol. 1). Księgarnia św. Wojciecha.

Łaski, J. (Ed.). (1506). Commune Incliti Poloniae regni privilegium constitutionum et indultuum publicitus decretorum approbatorumque [...] per [...] Alexandrum [...] Regem Poloniae [...]. J. Haller.

Lenartowicz-Zagrodna, A. (2011). Defensio verae translationis corporis Catechismi in linguam Polonicam, adversus calumnias Joannis Secluciani Jana Maleckiego - przekład wraz z komentarzem. Poznańskie Studia Polonistyczne. Seria Językoznawcza, 18(2), 107-144. https://doi.org/10.14746/pspsj.2011.18.2.7

Loska, T., \& Głodek, B. (Eds.). (1999). Mszał z czytaniami. Niedziele, uroczystości, święta, dni powszednie (3rd ed.). Księgarnia św. Jacka.

Łuczak, A. (2001). Najstarszy polski drukowany przekład Nowego Testamentu pióra Stanisława Murzynowskiego (1551-1553). In T. Jaworski \& W. Pyżewicz (Eds.), Nowy Testament $w$ dziejach i kulturze Europy: 450 rocznica przekładu Nowego Testamentu przez Mikołaja Jakubicę na język dolnołużycki. Wydawnictwo Szkoły Nauk Humanistycznych i Społecznych Uniwersytetu Zielonogórskiego.

Małłek, J. (1977). Murzynowski h. Ogończyk Stanisław. In Polski słownik biograficzny (Vol. 22). Instytut Historii Polskiej Akademii Nauk.

Małłek, J. (2001). Stanisław Murzynowski: Tłumacz Nowego Testamentu, pisarz religijny, osjandrysta, „servulus et clientulus” księcia Albrechta Pruskiego. In T. Jaworski \& W. Pyżewicz (Eds.), Nowy Testament $w$ dziejach i kulturze Europy: 450 rocznica przekładu Nowego Testamentu przez Mikołaja Jakubicę na język dolnołużycki. Wydawnictwo Szkoły Nauk Humanistycznych i Społecznych Uniwersytetu Zielonogórskiego.

Małłek, J., \& Pepłowski, F. (1974). Wstęp. In S. Murzynowski, Historyja żałosna a straszliwa o Franciszku Spierze oraz Ortografija polska. Pojezierze.

Masłej, D. (2016). Modlitwa Pańska w polskim średniowieczu. Znad staropolskich rękopisów. Wydawnictwo Rys.

Mayenowa, M. R. (1955). Walka o język w życiu i literaturze staropolskiej (2nd ed.). Państwowy Instytut Wydawniczy. 
Mirowicz, A. (Ed.). (1980a). Wielki stownik rosyjsko-polski: Vol. A-O. Wiedza Powszechna, Russkij Âzyk.

Mirowicz, A. (Ed.). (1980b). Wielki słownik rosyjsko-polski: Vol. P-Â. Wiedza Powszechna, Russkij Âzyk.

Nowo wydany Kancyonat Pruski... (K. Haberkant, Trans.). (1741). Jan Henryk Hartung.

Pietkiewicz, R. (2002). Pismo Święte w języku polskim w latach 1518-1638. Sytuacja wyznaniowa w Polsce a rozwój edytorstwa biblijnego [Rozprawa doktorska]. Uniwersytet Wrocławski Wydział Filologiczny Instytut Bibliotekoznawstwa.

Pismo Święte Starego i Nowego Testamentu w przekładzie z języków oryginalnych. (1965). Wydawnictwo Pallottinum.

Płoszek, H. (1991). Ewangelicy augsburscy - luteranie. Jednota, 8-9.

Rospond, S. (1949a). Stanisław Murzynowski obrońca języka ojczystego. In H. Barycz \& J. Hulewicz (Eds.), Studia z dziejów kultury polskiej. Gebethner i Wolff.

Rospond, S. (1949b). Studia nad językiem polskim XVI wieku (Jan Seklucjan, Stanisław Murzynowski, Jan Sandecki-Malecki, Grzegorz Orszak). Wrocławskie Towarzystwo Naukowe.

Taszycki, W. (1947). Przejście chwDf w staropolszczyźnie. Sprawozdania z Czynności i Posiedzeń Polskiej Akademii Umiejętności, 48(2).

Tregelles, S. P. (1854). An account of the printed text of the Greek New Testament: With remarks on its revision upon critical principles. Samuel Bagster and Sons.

Trypućko, J., Spandowski, M., \& Szyller, S. (Eds.). (2007). The catalogue of the book collection of the Jesuit College in Braniewo held in the University Library in Uppsala. Katalog księgozbioru Kolegium Jezuitów w Braniewie zachowanego w Bibliotece Uniwersyteckiej w Uppsali: Vol. 2: Druki XVI-XVII w. The 16th and 17th century books. Biblioteka Narodowa, Uppsala Universitetsbibliotek.

Warmiński, I. (1906). Andrz. Samuel i Jan Seklucyan. Księgarnia św. Wojciecha (Poznań), Skł. gł. Księgarnia G. Gebethnera i Sp. (Kraków).

Węgrzyniak, W. (2019). o co właściwie nam chodzi? Nie piszę, by się inni zgadzali (M. Pabis, Ed.). Dom Wydawniczy Rafael.

Wieczorkiewicz, B., \& Sinielnikoff, R. (1965). Elementy gramatyki historycznej języka polskiego z ćwiczeniami (2nd ed.). Państwowe Zakłady Wydawnictw Szkolnych.

Wollek, C. (1972). Das Domkapitel von Ptock 1524-1564. Gegenreformatorische Haltung und innerkirchliche Reformbestrebungen. Böhlau Verlag.

Wróbel, A. (2003). O dialektyzmach i regionalizmach dobrzyńskich w twórczości Stanisława Murzynowskiego. Notatki Płockie, 48(4), 3-11.

Zolli, E. (2015). Nazarejczyk (A. J. Katolo, Trans.). Fundacja Instytut Globalizacji. 